\title{
Pengaruh Kualitas Tidur terhadap Kejadian Akne Vulgaris
}

\author{
Deshinta Dumgair, ${ }^{1}$ Herry E. J. Pandaleke, ${ }^{2}$ Marlyn G. Kapantow ${ }^{2}$
}

\author{
${ }^{1}$ Program Studi Pendidikan Dokter Fakultas Kedokteran Universitas Sam Ratulangi, Manado, \\ Indonesia \\ ${ }^{2}$ Bagian Ilmu Kesehatan Kulit dan Kelamin Fakultas Kedokteran Universitas Sam Ratulangi, \\ Manado, Indonesia \\ Email: dumgaird@gmail.com
}

\begin{abstract}
Acne vulgaris is a chronic pilosebaceous follicle inflammation andi its highest prevalence is on 16-17-year-olds. Factors influencing or triggering acne vulgaris are sebum, genetics, hormones, diet, stress, and cosmetics. Inadequate and unqualified sleep may disrupt physiological and psychological balances, and is estimated to increase androgen hormone activities. This study was aimed to obtain the effect of sleep quality on acne vulgaris incidence. This was a literature review using three databases, as follows: PubMed, ClinicalKey, and Google Scholar. Keywords used were "Kualitas Tidur" DAN "Akne Vulgaris" (Indonesian), and "Sleep quality" AND "Acne Vulgaris" (English). The results obtained 10 literature matching the inclusion and exclusion criteria. The number of samples suffered from acne vulgaris with poor sleep quality was higher than of samples with good sleep quality. There were more male samples than female samples in all literatures in the study. In conclusion, poor sleep quality could trigger and contribute in the development of acne vulgaris.
\end{abstract}

Keywords: sleep quality, acne vulgaris, severity degree

\begin{abstract}
Abstrak: Akne vulgaris merupakan peradangan kronis folikel polisebasea dengan prevalensi tertinggi pada usia 16-17 tahun. Faktor yang memengaruhi atau mencetuskan akne vulgaris yaitu sebum, genetik, hormon, diet, stres, dan kosmetik. Tidur yang tidak adekuat dan berkualitas dapat mengakibatkan gangguan keseimbangan fisiologis, dan psikologis, serta diperkirakan dapat menyebabkan aktivitas hormon androgen meningkat. Penelitian ini bertujuan untuk mengetahui pengaruh kualitas tidur terhadap kejadian akne vulgaris. Jenis penelitian ialah literature review dengan pencarian data menggunakan tiga database yaitu PubMed, ClinicalKey dan Google Scholar. Kata kunci yang digunakan yaitu "Kualitas Tidur" DAN "Akne Vulgaris" (Bahasa Indonesia), serta "Sleep quality" AND "Acne Vulgaris" (Bahasa Inggris). Hasil penelitian mendapatkan 10 literatur yang sesuai dengan kriteria inklusi dan ekslusi. Sampel yang memiliki kualitas tidur buruk dan menderita akne vulgaris lebih banyak daripada sampel yang memiliki kualitas tidur baik dan menderita akne vulgaris. Derajat keparahan akne vulgaris paling banyak derajat sedang. Total sampel laki-laki lebih banyak dibandingkan dengan perempuan pada semua literatur yang digunakan dalam penelitian. Simpulan penelitian ini ialah kualitas tidur yang buruk dapat mengakibatkan timbulnya akne vulgaris dan juga menjadi salah satu faktor yang berkontribusi dalam perkembangan akne vulgaris.
\end{abstract}

Kata kunci: kualitas tidur, akne vulgaris, tingkat keparahan

\section{PENDAHULUAN}

Akne vulgaris merupakan peradangan kronis folikel polisebasea dengan manifestasi klinis berupa komedo, papul, pustul, nodus serta kista. Tempat predileksi akne vulgaris ialah pada wajah dan leher (99\%), punggung $(60 \%)$, dada, serta bahu dan lengan atas $(15 \%)$. Akne vulgaris umumnya dimulai pada usia 12-15 tahun, dengan puncak tingkat keparahan pada usia 17-21 
tahun. Akne vulgaris merupakan penyakit terbanyak pada remaja usia $15-18$ tahun. ${ }^{1}$

Insiden akne vulgaris ialah $80-100 \%$ pada dewasa muda yaitu pada perempuan berusia 14-17 tahun dan pada laki-laki berusia 16-19 tahun. Prevelansi tertinggi pada usia 16-17 tahun, pada perempuan berkisar $83-85 \%$ dan pada laki-laki berkisar $95-100 \% .^{2}$

Penyebab pasti timbulnya akne vulgaris belum diketahui namun akne vulgaris merupakan penyakit kulit yang multifaktorial karena banyak faktor yang dihubungkan sebagai penyebab terjadinya akne vulgaris. Faktor-faktor yang memengaruhi atau mencetuskan akne vulgaris yaitu sebum, genetik, hormon, diet, stres, dan kosmetik. ${ }^{3}$

Tidur terlalu larut malam diperkirakan dapat menyebabkan aktivitas hormon androgen meningkat. Hormon androgen berperan penting dalam regulasi mekanisme produksi sebum. Produksi sebum yang berlebihan akan menyebabkan kulit menjadi berminyak dan akan menimbulkan sumbatan pada kelenjar polisebasea yang mengakibatkan timbulnya akne vulgaris, sehingga kulit berminyak cenderung lebih mudah terjadi akne vulgaris dibandingkan kulit normal dan kering. ${ }^{4}$

Tidur merupakan salah satu kebutuhan dasar bagi manusia. Manfaat tidur akan dirasakan bila seseorang memiliki kualitas tidur yang baik. Kualitas tidur menunjukkan adanya kemampuan individu untuk tidur dan memperoleh jumlah istirahat yang sesuai dengan kebutuhannya. Tidur yang tidak adekuat dan berkualitas dapat mengakibatkan gangguan keseimbangan baik fisiologik maupun psikologik.,

Berdasarkan latar belakang yang telah diuraikan peneliti tertarik untuk melakukan penelitian literature review yang membahas dan menelaah berbagai informasi mengenai pengaruh kualitas tidur terhadap kejadian akne vulgaris.

\section{METODE PENELITIAN}

Penelitian ini bertujuan untuk mengetahui pengaruh kualitas tidur dengan kejadian akne vulgaris. Jenis penelitian ini ialah literature review. Pencarian data menggunakan tiga database yaitu PubMed, ClinicalKey dan Google Scholar dengan menggunakan kata kunci "Kualitas Tidur" DAN "Akne Vulgaris"(Bahasa Indonesia), serta "Sleep quality" AND "Acne Vulgaris" (Bahasa Inggris). Artikel atau jurnal yang sesuai dengan kriteria inklusi dan eksklusi diambil untuk selanjutnya dianalisis.

\section{HASIL PENELITIAN}

Setelah melalui tahap seleksi studi, didapatkan sepuluh literatur yang memenuhi kriteria inklusi dan ekslusi. Dari kesepuluh literatur tersebut, terdapat sembilan penelitian cross-sectional study dan satu penelitian case control study. Tabel 1 memperlihatkan nama peneliti, tahun publikasi, jumlah sampel, dan hasil penelitian dari masing-masing literatur.

Tabel 1. Hasil penelitian masing-masing literatur

\begin{tabular}{|c|c|c|c|c|}
\hline No. & $\begin{array}{c}\text { Peneliti, tahun, dan } \\
\text { judul }\end{array}$ & $\begin{array}{l}\text { Jumlah } \\
\text { sampel }\end{array}$ & $\begin{array}{l}\text { Study design } \\
\text { dan uji } \\
\text { statistik }\end{array}$ & Hasil penelitian \\
\hline 1. & $\begin{array}{l}\text { Oktarina R et al, } 2018^{7} \\
\text { Pengaruh kualitas, } \\
\text { kuantitas tidur, dan ke- } \\
\text { biasaan merokok terha- } \\
\text { dap tingkat keparahan } \\
\text { akne vulgaris }\end{array}$ & $\mathrm{L}=68$ & $\begin{array}{l}\text { Study design } \\
\text { cross-sectional } \\
\text { Uji statistik } \\
\text { Chi-Square }\end{array}$ & $\begin{array}{l}\text { Terdapat } 17(50 \%) \text { menderita AV derajat ringan, } \\
14(41,2 \%) \text { menderita AV derajat sedang, } 3 \\
(8,8 \%) \text { menderita AV berat yang mengalami } \\
\text { kualitas tidur baik dan terdapat } 4(11,8 \%) \\
\text { menderita AV derajat ringan, } 22(64,7 \%) \\
\text { menderita AV derajat sedang, } 8(23,5 \%) \\
\text { menderita AV derajat berat yang mengalami } \\
\text { kualitas tidur buruk. Didapatkan hasil nilai } \\
\text { p=0,002 (nilai p } \leq 0,05) \text { maka terdapat hubungan } \\
\text { bermakna antara kualitas tidur dengan tingkat } \\
\text { keparahan AV. }\end{array}$ \\
\hline
\end{tabular}


2. Djunarko JC, $2017^{8}$ Hubungan kualitas tidur dengan kejadian akne vulgaris pada lakilaki pekerja swasta: studi pada karyawan perusahaan swasta di wilayah Kota Semarang

3. Pujiastuti DS, $2012^{9}$ Hubungan antara waktu tidur malam dengan terjadinya akne vulgaris di RSU Dr. Soedarso Pontianak

4. Silvia E et al, $2019^{10}$ Hubungan antara kualitas tidur dengan acne vulgaris pada mahasiswa Fakultas Kedokteran Umum Universitas Malahayati Angkatan 2019

5. Harlim A, $2018^{11}$

The relationship between sleep quality and students' acne vulgaris severity at Medical Faculty Universitas Kristen Indonesia

6. Malahayati D, $2017^{3}$ Hubungan antara kua-
litas tidur dengan tingkat keparahan akne vulgaris di SMAN 2 Sukoharjo
$\mathrm{L}=138$

Study design cross-sectional Uji statistik Chi-Square
157 mahasiswa Kedokteran, tidak tertera pada jurnal jumlah laki-laki dan perempuan

$\mathrm{P}=56$
$\mathrm{~L}=31$

$\mathrm{P}=54$

$\mathrm{L}=8$
Study design cross-sectional Uji statistik Chi-Square

Study design cross-sectional Uji statistik Chi-Square Terdapat $28(75,7 \%)$ menderita AV dan 9 $(24,3 \%)$ tidak menderita AV yang mengalami kualitas tidur baik. Didapatkan juga $56(93,3 \%)$ menderita AV dan $4(6,7 \%)$ tidak menderita AV yang mengalami kualitas tidur buruk. Hasil menunjukkan hubungan kualitas tidur terhadap kejadian akne vulgaris pada laki-laki pekerja swasta didapatkan hasil nilai $\mathrm{p}=0,028$. Nilai $\mathrm{p}<$ 0,05 , yang berarti bahwa terdapat hubungan bermakna antara hubungan kualitas tidur terhadap kejadian akne vulgaris pada laki-laki pekerja swasta.

Data hasil penelitian terdiri dari 20 orang $(14,50 \%)$ mengalami akne vulgaris yang memiliki kebiasaan tidur < pukul 22.00 WIB, 34 orang $(24,64 \%)$ tidak mengalami akne vulgaris yang memiliki kebiasaan tidur <pukul 22.00 WIB, 48 orang $(34,78 \%)$ mengalami akne vulgaris yang memiliki kebiasaan tidur $\geq$ pukul 22.00 WIB dan 36 orang (26,08\%) tidak mengalami akne vulgaris yang memiliki kebiasaan tidur $\geq$ pukul 22.00 WIB. Hasil menunjukkan bahwa terdapat hubungan yang bermakna antara kebiasaan waktu tidur $\geq$ pukul 22.00 WIB dengan terjadinya akne vulgaris dengan nilai $\mathrm{p}=0,021(\mathrm{p}<0,05)$.

Dari 119 sampel dengan kualitas tidur buruk yang mengalami acne vulgaris positif sebanyak 105 sampel $(88,2 \%)$ dan yang mengalami acne vulgaris negatif sebanyak 14 sampel $(11,8 \%)$. Sedangkan dari 38 sampel dengan kualitas tidur baik yang mengalami acne vulgaris positif sebanyak 7 sampel $(18,4 \%)$ dan yang mengalami acne vulgaris negatif sebanyak 31 sampel $(81,6 \%)$. Nilai $\mathrm{p}=0,000$. Hal ini menunjukkan terdapat hubungan antara kualitas tidur dengan acne vulgaris.

Terdapat $23(71,9 \%)$ menderita AV derajat ringan yang mengalami kualitas tidur baik dan $9(28,1 \%)$ menderita AV derajat ringan yang mengalami kualitas tidur buruk. Terdapat 4 $(7,3 \%)$ menderita AV berat yang mengalami kualitas tidur baik dan $51(92,7 \%)$ menderita AV berat yang mengalami kualitas tidur buruk. Didapatkan hasil $\mathrm{p}=0,000(\mathrm{p}<0,05)$ yang berarti terdapat hubungan bermaknas antara kualitas tidur dan tingkat keparahan acne vulgaris pada mahasiswa Fakultas Kedokteran Universitas Kristen Indonesia.

Studydesign Terdapat $38(74,5 \%)$ menderita AV derajat cross-sectional ringan, $12(23,5 \%)$ menderita AV derajat seUji statistik dang, $1(2,0 \%)$ menderita AV berat yang mengaChi-Square lami kualitas tidur buruk dan terdapat $4(36,4 \%)$ menderita AV derajat ringan, $6(54,5 \%)$ menderita AV derajat sedang, $1(9,10 \%)$ menderita AV derajat berat yang mengalami kualitas tidur baik. Didapatkan hasil $\mathrm{p}=0,041$. Oleh karena nilai p<0,05 maka dapat diambil kesimpulan bahwa terdapat hubungan yang bermakna hubungan kualitas tidur dengan tingkat keparahan akne vulgaris di SMAN 2 Sukoharjo. 


\begin{tabular}{|c|c|c|c|c|}
\hline 7. & $\begin{array}{l}\text { Primadani AA, } 2015^{12} \\
\text { Hubungan tidur larut } \\
\text { malam terhadap tim- } \\
\text { bulnya akne vulgaris } \\
\text { pada mahasantri putra } \\
\text { Pesantren International } \\
\text { K.H Mas Mansur UMS } \\
2015\end{array}$ & $\mathrm{~L}=70$ & $\begin{array}{l}\text { Study design } \\
\text { cross-sectional } \\
\text { Uji statistik } \\
\text { Chi-Square }\end{array}$ & $\begin{array}{l}\text { Terdapat } 28(80 \%) \text { menderita AV dan } 7(20 \%) \\
\text { tidak menderita AV yang tidur larut malam. } \\
\text { Didapatkan juga } 10(28,6 \%) \text { menderita AV dan } \\
25(71,4 \%) \text { tidak menderita AV yang tidak tidur } \\
\text { larut malam. Didapatkan hasil p=0,000 (p } \\
<0,05) \text { yang artinya bahwa ada hubungan yang } \\
\text { signifikan antara tidur larut malam dengan } \\
\text { timbulnya akne vulgaris pada mahasantri putra } \\
\text { pesantren K.H Mas Mansur UMS. }\end{array}$ \\
\hline 8. & $\begin{array}{l}\text { Rajoo SS, } 2016^{13} \\
\text { Hubungan kualitas ti- } \\
\text { dur dengan kejadian } \\
\text { akne vulgaris pada ma- } \\
\text { hasiswa Fakultas Ke- } \\
\text { dokteran Universitas } \\
\text { Sumatera Utara angkat- } \\
\text { an } 2013\end{array}$ & $\begin{array}{l}\mathrm{P}=72 \\
\mathrm{~L}=28\end{array}$ & $\begin{array}{l}\text { Study design } \\
\text { Case control } \\
\text { study } \\
\text { Uji statistik } \\
\text { Chi-Square }\end{array}$ & $\begin{array}{l}\text { Pada kelompok kualitas tidur baik dengan akne } \\
\text { vulgaris negatif berjumlah } 17 \text { orang }(17 \%) \text { dan } \\
\text { akne vulgaris positif berjumlah } 7 \text { orang }(7 \%) \text {. } \\
\text { Pada kelompok kualitas tidur tidak baik, sampel } \\
\text { dengan akne vulgaris negatif berjumlah } 33 \\
\text { orang }(33 \%) \text { dan akne vulgaris positif berjumlah } \\
43 \text { orang }(43 \%) \text {. Didapatkan p=0,019, lebih } \\
\text { kecil dari nilai } \alpha \text { yang ditetapkan }(\alpha<0,05) \text {. Hal } \\
\text { ini berarti terdapat hubungan bermakna dan } \\
\text { perbedaan proposi kejadian akne vulgaris pada } \\
\text { mahasiswa dengan kualitas tidur baik dan } \\
\text { mahasiswa dengan kualitas tidur tidak baik. }\end{array}$ \\
\hline 9. & $\begin{array}{l}\text { Sinaga AAS, } 2018^{14} \\
\text { Hubungan kualitas ti- } \\
\text { dur dengan tingkat ke- } \\
\text { parahan akne vulgaris } \\
\text { pada siswa SMA Yos } \\
\text { Sudarso Batam }\end{array}$ & $\begin{array}{l}\mathrm{P}=54 \\
\mathrm{~L}=46\end{array}$ & $\begin{array}{l}\text { Study design } \\
\text { cross-sectional } \\
\text { Uji statistik } \\
\text { Chi-Square }\end{array}$ & $\begin{array}{l}\text { Responden yang memiliki kualitas tidur baik, } 22 \\
\text { orang }(22 \%) \text { menderita akne derajat ringan, } 16 \\
\text { orang }(16 \%) \text { menderita akne derajat sedang, dan } \\
3 \text { orang }(3 \%) \text { menderita akne derajat berat. Pada } \\
\text { responden yang memiliki kualitas tidur buruk, } \\
36 \text { orang }(36 \%) \text { menderita akne derajat ringan, } \\
17 \text { orang }(17 \%) \text { menderita akne derajat sedang, } \\
\text { dan } 6 \text { orang }(6 \%) \text { menderita akne derajat berat. } \\
\text { Hasil tidak ditemukan hubungan antara kualitas } \\
\text { tidur dengan tingkat keparahan akne vulgaris } \\
\text { pada siswa SMA Yos Sudarso Batam ( } \mathrm{p}=0,546 \\
>\alpha=0,05) \text {. }\end{array}$ \\
\hline 10. & $\begin{array}{l}\text { Fang RA, } 2019^{6} \\
\text { Hubungan kualitas ti- } \\
\text { dur dengan tingkat ke- } \\
\text { parahan akne vulgaris } \\
\text { pada mahasiswa Fakul- } \\
\text { tas Kedokteran Univer- } \\
\text { sitas Sumatera Utara } \\
\text { tahun } 2019\end{array}$ & $\begin{array}{l}\mathrm{P}=49 \\
\mathrm{~L}=51\end{array}$ & $\begin{array}{l}\text { Study design } \\
\text { cross-sectional } \\
\text { Uji statistik } \\
\text { Chi-Square }\end{array}$ & $\begin{array}{l}\text { Responden yang memiliki kualitas tidur yang } \\
\text { baik, } 4 \text { orang ( } 4 \% \text { ) diantaranya menderita akne } \\
\text { vulgaris ringan, } 17 \text { orang }(17 \%) \text { menderita akne } \\
\text { vulgaris sedang, dan } 3 \text { orang }(3 \%) \text { menderita } \\
\text { akne vulgaris berat. Sedangkan pada responden } \\
\text { yang memiliki kualitas tidur buruk, } 32 \text { orang } \\
(32 \%) \text { menderita akne vulgaris ringan, } 37 \text { orang } \\
(37 \%) \text { menderita akne vulgaris sedang, dan } 7 \\
\text { orang ( } 7 \%) \text { menderita akne vulgaris berat. Hasil } \\
\text { tidak ada hubungan antara kualitas tidur dengan } \\
\text { tingkat keparahan akne vulgaris pada mahasiswa } \\
\text { FK USU tahun } 2019(\mathrm{p}=0,077>\alpha=0,05) \text {. }\end{array}$ \\
\hline
\end{tabular}

\section{BAHASAN}

Berdasarkan literatur yang telah dipilih, sampel yang memiliki kualitas tidur buruk dan menderita akne vulgaris lebih banyak daripada sampel yang memiliki kualitas tidur baik dan menderita akne vulgaris. Tiga literatur mendapatkan jumlah sampel yang mengalami kualitas tidur buruk dan menderita akne vulgaris lebih dari $60 \%$ sampel, $8,10,12$ dua literatur mendapatkan jumlah sampel yang mengalami kualitas tidur buruk dan menderita akne vulgaris kurang dari $60 \% .^{9,13}$ Selanjutnya dua literatur juga mendapatkan kurang dari $60 \%$ sampel yang mengalami kualitas tidur buruk diikuti dengan timbulnya akne vulgaris sesuai dengan derajat keparahannya, ${ }^{6,14}$ dan tiga literatur mendapatkan lebih dari $60 \%$ sampel yang mengalami kualitas tidur buruk diikuti dengan timbulnya akne vulgaris sesuai dengan derajat keparahannya. .,7,11 $^{\text {Derajat }}$ keparahan akne vulgaris paling banyak ialah 
derajat sedang. Dari sepuluh literatur, terdapat lima literatur yang mendapatkan hubungan bermakna antara kualitas tidur dengan kejadian akne vulgaris dan tiga literatur yang mendapatkan hubungan bermakna antara kualitas tidur dengan tingkat keparahan akne vulgaris. Semua yang telah dijelaskan terjadi karena kualitas tidur buruk yang menyebabkan penurunan hormon melatonin. Hormon melatonin dikeluarkan pada malam hari oleh kelenjar pineal dan bertanggung jawab untuk pengaturan jam tubuh pada setiap individu. Sekresi melatonin mempunyai efek terhadap kecenderungan mengantuk, serta memengaruhi kualitas dan kuantitas tidur. Tidur terlalu larut memiliki kaitan bermakna dengan penurunan hormon melatonin yang berfungsi untuk menekan sintesis androgen, Rendahnya hormon melatonin menyebabkan peningkatan sintesis hormon androgen, yang selanjutnya menyebabkan meningkatnya sekresi kelenjar sebum yang berakibat terjadinya akne vulgaris. ${ }^{8,10}$

Berdasarkan jenis kelamin, total sampel laki-laki lebih banyak dibandingkan perempuan pada semua literatur yang digunakan dalam penelitian ini. Hal ini diduga karena laki-laki cenderung kurang baik dalam hal memperhatikan kebersihan diri, sehingga meningkatkan kemungkinan timbulnya akne. Laki-laki juga cenderung kurang memiliki kesadaran untuk mencari informasi dan mencari pelayanan kesehatan dalam menangani masalah akne. Dibandingkan perempuan, populasi laki-laki dianggap lebih homogen karena kurangnya faktor-faktor ekstrinsik seperti penggunaan kosmetik dan produk perawatan wajah sehingga dianggap sebagai populasi penelitian yang tepat. ${ }^{15}$

Penelitian Pujiastuti ${ }^{9}$ mendapatkan bahwa tidur pada remaja sampai dewasa muda (16-30 tahun) mempunyai pola yang berbeda dibandingkan usia lainnya. Hal ini disebabkan oleh perubahan hormonal yang terjadi diakhir masa pubertas. Remaja mengalami pergeseran irama sirkadian, sehingga jam tidur pun bergeser. Sejalan dengan penelitian Malahayati ${ }^{3}$ yang melaporkan bahwa sampel dengan kualitas tidur buruk lebih banyak dibandingkan dengan sampel kualitas tidur baik yaitu sebanyak $82,3 \%$ dengan kualitas tidur buruk. Hal ini terjadi karena banyak sampel yang mengalami kesulitan dalam memulai tidur, durasi tidur yang singkat, dan mengalami gangguan ketika tidur seperti: terbangun di tengah malam atau terlalu dini, tidak mampu tidur nyenyak, kedinginan atau kepanasan, mimpi buruk, batuk atau mengorok sehingga hanya memiliki durasi tidur sebanyak 46 jam. Remaja memiliki kualitas tidur yang buruk karena harus menghadapi ujian sekolah, membuat tugas yang menumpuk, penggunaan alat elektronik seperti ponsel dan komputer secara berlebihan juga menyebabkan remaja untuk menunda tidur sehingga mengalami kekurangan tidur dan berakibat kepada buruknya kualitas tidur dan juga hal ini menyebabkan stres. ${ }^{3}$

Dari sepuluh literatur didapatkan dua literatur yang melaporkan bahwa tidak terdapat hubungan antara kualitas tidur dengan tingkat keparahan akne vulgaris. Menurut Sinaga, ${ }^{14}$ hal ini terjadi diduga akibat tidak meratanya distribusi derajat akne pada seluruh responden. Fang ${ }^{6}$ berpendapat bahwa hal ini diduga terjadi oleh dua hal, yaitu: 1) adanya faktor risiko dari akne vulgaris yang sulit untuk diintervensi oleh peneliti yaitu faktor hormonal; dan 2) tidak meratanya distribusi derajat akne pada responden dalam penelitian yang dilakukan. Akne vulgaris merupakan penyakit kulit yang multifaktorial. Bila didapatkan hasil tidak adanya hubungan/pengaruh kualitas tidur dengan kejadian akne vulgaris, hal ini bisa terjadi karena banyaknya faktor predisposisi lain yang menyebabkan akne vulgaris yaitu genetik, diet, paparan sinar matahari, merokok dan kebersihan kulit. ${ }^{16}$

\section{SIMPULAN}

Kualitas tidur yang buruk dapat mengakibatkan timbulnya akne vulgaris dan juga menjadi salah satu faktor yang berkontribusi dalam perkembangan akne vulgaris.

Diperlukan edukasi kepada masyarakat terutama remaja dan dewasa muda untuk lebih mengetahui berbagai faktor yang dapat 
memicu timbulnya akne vulgaris seperti tidur larut malam. Diharapkan juga adanya penelitian lebih lanjut tentang kualitas tidur dengan akne vulgaris.

\section{Konflik Kepentingan}

Penulis menyatakan tidak terdapat konflik kepentingan dalam studi ini.

\section{DAFTAR PUSTAKA}

1. Sitohang IBS, Wasitatmadja SM. Akne Vulgaris. In: Menaldi SLS, Bramono K, Indriatmi W, editors. Ilmu Penyakit Kulit dan Kelamin (7th ed). Jakarta: Badan Penerbit FKUI, 2017; p. 288-91.

2. Sibero HT, Sirajudin A, Anggraini DI. Prevalensi dan gambaran epidemiologi akne vulgaris di Provinsi Lampung. JK Unila. 2019;3(2):308-11.

3. Malahayati D. Hubungan antara kualitas tidur dengan tingkat keparahan akne vulgaris di SMAN 2 Sukoharjo [Skripsi]. Surakarta: Universitas Muhammadiyah Surakarta; 2018.

4. Kamil M. Hubungan kualitas tidur dengan timbulnya akne vulgaris pada pelajar SMKI PERTI. Jakarta: Universitas Trisakti; 2016.

5. Sulistiyani C. Beberapa faktor yang berhubungan dengan kualitas tidur pada mahasiswa Fakultas Kesehatan Masyarakat Universitas Diponegoro Semarang. Jurnal Kesehatan Masyarakat. 2012;1(2):280-92.

6. Fang RA. Hubungan kualitas tidur dengan tingkat keparahan akne vulgaris pada mahasiswa Fakultas Kedokteran Universitas Sumatera Utara Tahun 2019 [Skripsi]. Medan: Universitas Sumatera Utara; 2019.

7. Oktarina R, Sari MA, Prakoeswa FRS. Pengaruh kualitas, kuantitas tidur, dan kebiasaan merokok terhadap tingkat keparahan akne vulgaris. National Symposium and Workshop Continuing Medical Education XIII. Available from: https://publikasiilmiah.ums.ac.id/bitstre am/handle/11617/11227/19.pdf?sequen ce $=1 \&$ isAllowed $=\mathrm{y}$

8. Djunarko JC, Widayati RI, Julianti HP. Hubungan kualitas tidur dengan kejadian akne vulgaris pada laki-laki pekerja swasta Studi pada karyawan perusahaan swasta di wilayah Kota Semarang. Jurnal Kedokteran Diponegoro. 2018; 7(2):1000-11.

9. Pujiastuti DS. Hubungan antara waktu tidur malam dengan terjadinya akne vulgaris di RSU DR. Soedarso Pontianak [Naskah Publikasi]. 2012 [cited 2020 Sept 22]. Available from: http://download. portalgaruda.org/art\%0Aicle.php?articl $\mathrm{e}=111616 \& \mathrm{val}=2307$

10. Silvia E, Febriyani A, Nando R, Riza A. Hubungan antara kualitas tidur dengan acne vulgaris pada mahasiswa Fakultas Kedokteran Umum Universitas Malahayati Angkatan 2019. Jurnal Medika Malahayati. 2020;4(1):33-8.

11. Harlim A, Tesalonika SGS. The Relationship between Sleep Quality and Students' Acne Vulgaris Severity at Medical Faculty Universitas Kristen Indonesia. Jakarta: Universitas Kristen Indonesia; 2018.

12. Primadani AA. Hubungan Tidur Larut Malam Terhadap Timbulnya Akne Vulgaris Pada Mahasantri Putra Pesantren International K.H Mas Mansur Ums 2015. 2015 [cited 2020 Sept 17]. Available from: http://www.ti.com/lit/ ds/symlink/cc2538.html

13. Selva RS. Hubungan kualitas tidur dengan kejadian akne vulgaris pada mahasiswa Fakultas Kedokteran Universitas Sumatera Utara Angkatan 2013. 2016 [cited 2020 Sept 17]. Available from: http: //repositori.usu.ac.id/handle/123456789 /19954\%0A

14. Sinaga SAA. Hubungan kualitas tidur dengan tingkat keparahan akne vulgaris pada siswa SMA Yos Sudarso Batam. 2018 [cited 2020 Sept 23]. Available from: http://repositori.usu.ac.id/handle/12345 6789/11019

15. Purwaningdyah RAK, Jusuf NK. Profil penderita akne vulgaris pada siswasiswi di SMA Shafiyyatul Amaliyyah. E-Jurnal Fakultas Kedokteran USU. 2013;1(1):1-8.

16. Agustin YC, Hikmawati D, Nuripah G. Hubungan kualitas tidur pada mahasiswa dengan akne vulgaris di Fakultas Kedokteran Unisba. 2017;3(2):493- 